\title{
Influence of temperature and conductivity on the life-history characteristics of a pampean strain of Brachionus plicatilis
}

\author{
NOELIA S. FERRANDO, MARÍA C. CLAPS, HERNÁN H. BENÍTEZ and NÉSTOR A. GABELLONE \\ Instituto de Limnología Dr. Raúl A. Ringuelet/CCT-CONICET La Plata, FCNyM, UNLP, \\ Boulevard 120 y 62, 1900 La Plata, Provincia de Buenos Aires, Argentina
}

Manuscript received on June 12, 2017; accepted for publication on October 9, 2017

\begin{abstract}
In the present work, we provide the first approach about the life-history of Brachionus plicatilis in South America. We tested with laboratory experiments the response of the pampean strain of B. plicatilis for two of its main stressors (conductivity and temperature). We evaluated the effects of eight conductivity values from 1 to $17 \mathrm{mS} . \mathrm{cm}^{-1}$ and two temperatures $\left(15\right.$ and $\left.25^{\circ} \mathrm{C}\right)$ to compare its abundance with those obtained in the pampean lotic and lentic environments, where this rotifer is frequent or dominant. The results demonstrated that the increase in population-growth rate and the peak of abundance occurred at the highest temperature and at medium conductivity. Minimum values were obtained at the lowest temperature and conductivities analyzed, but the final density attained was nevertheless similar to those recorded in the pampean environments at the optimum conductivity and during the spring and summer seasons. Males, mictic females, and resting eggs were observed at the minimum and maximum conductivities, revealing the strategy of this species for maintaining dominance in environments with fluctuating salinity. The experiments also indicated the possible behavior of this relevant member of the zooplankton community within a scenario of increasing temperature and salinity related to the climate changes occurring in the pampean region.
\end{abstract}

Key words: euryhaline rotifer, experimental cultures, growth rate, salinity, temperature.

\section{INTRODUCTION}

Natural populations of the euryhaline rotifer Brachionus plicatilis are found in aquatic environments including freshwater, brackish, and marine ecosystems where this species can tolerate salinities up to 97 parts per thousand (Lubzens et al. 1985). This rotifer is one of the most useful foods for the intensive culture of marine larval fish

Correspondence to: Noelia Soledad Ferrando

E-mail: nferrando@ilpla.edu.ar and crustaceans (Lubzens et al. 2001). For many years, the species was categorized as cosmopolitan and euryoecious, whereas recently the taxon is considered as a complex of cryptic species (Gómez et al. 2002, Suatoni et al. 2006, Gabaldón et al. 2016). The DNA evidence reveals the existence of 15 species within the complex (Mills et al. 2016). Some authors demonstrated that the coexistence of some of these cryptic species is favored by differences in their response to fluctuating salinity and temperature conditions and by differences 
in life-history traits (Montero-Pau et al. 2011, Gabaldón et al. 2015). Historically, it has been reported that the reproduction of $B$. plicatilis depends on numerous environmental conditions such as temperature, salinity, and the quality and quantity of food (Lubzens et al. 1995, Miracle and Serra 1989, Yúfera 2007). The temperature required for the highest reproduction rate differs among clones and geographical strains (Lubzens et al. 1989, 2001, Hotos 2002). Many studies have demonstrated that rotifer production is affected by the algae used as food (Cabrera et al. 2005, Suchar and Chigbu 2006) and that Chlorella vulgaris is one of the most commonly employed for that purpose (Hotos 2003). Salinity-through its major ecological and aquacultural influences-is a key environmental condition affecting the rotifer's growth and reproduction. Experiments with Brachionus rotundiformis have shown how the increasing salinity level, the decreasing food level, and the presence of crustacean zooplankters have adversely affected its population growth (Cheng et al. 2011). In 2005, Lowe et al. 2005 demonstrated that $B$. plicatilis is osmoregulatory, but this ability involves a toll on the rotifer's growth rate and egg production at high salinity levels. In this regard, certain investigations have demonstrated that Brachionus species can better tolerate a shift to higher salinities than to lower ones (Malekzadeh Viayeh et al. 2010). Moreover, Yin and Zhao (2008) concluded from their experiments that salinity had a notable effect on the population increase of $B$. plicatilis, though that influence was clone-specific. In Argentina, the species has been recorded in many localities (Ferrando and Claps 2016); but a high abundance has been noted throughout the annual cycle in temporary and permanent saline shallow lakes of the La Pampa province (Echaniz et al. 2006, 2013, Vignatti et al. 2012), and also in lotic environments such as the shallow lakes of the Santa Fe province, those being characterized by conductivities between 2.5 and $7.0 \mathrm{mS} . \mathrm{cm}^{-1}$ depending on associated saline river discharges (José de Paggi and Paggi 1998, José de Paggi and Devercelli 2011). In the Buenos Aires province, $B$. plicatilis is spatiotemporally predominant in the Salado River basin during extreme droughts or with salinities above $3.0 \mathrm{mS} . \mathrm{cm}^{-1}$ during the summer or winter periods (at temperatures lower than 12 ${ }^{\circ} \mathrm{C}$ ) promoting a concurrent general decrease in the specific richness of zooplankton (Gabellone et al. 2013, 2014), but the species has also been recorded in low densities at conductivities of less than 2.0 $\mathrm{mS} . \mathrm{cm}^{-1}$ and temperatures ranging from 7 to 30 ${ }^{\circ} \mathrm{C}$ (Claps et al. 2009). Bazzuri (2016) reported both types "L" and "S" of B. plicatilis evaluating morphological attributes in canals and tributaries located at headwaters of the Salado River basin. At the present time, some preliminary analyses were already performed since molecular identification of the pampean strain of the $B$. plicatilis complex is an essential objective.

Numerous studies have evaluated the responses of the members of this species to changes in conductivity (Pascual and Yúfera 1983, Vallejo et al. 1993, Sarma et al. 2006) and temperature (Yin and Zhao 2008, Fielder et al. 2000, among others). In Argentina, and more specifically in the Salado River basin, information has been reported on the optima and ranges of the species related to these parameters in field work on seasonal periodicity (Claps et al. 2009).

The present investigation aim was to provide experimental information on the life-history characteristics and population dynamics of a local strain of $B$. plicatilis related to the different conductivities and temperatures representative of those measured in the Salado River basin during recent decades. In the laboratory, specific responses involving fluctuations in the abundance of the natural populations of this strain can be determined to play a principal role in the majority of the environments where those changes occur. These results will also be useful for comparison 
with other strains since the generation of such clones causes different responses to the influence of specific environmental conditions such as salinity and temperature.

\section{MATERIALS AND METHODS}

\section{ISOLATION, CULTURE AND ACCLIMATION}

The individuals of Brachionus plicatilis used in both experiments were originally collected in the Mercante Canal (35 25' 59' S, 60 56'33' W) and

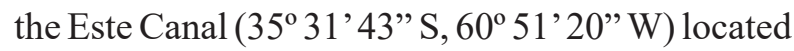
at the headwaters of the Salado River basin (Buenos Aires province). In these samples, two types of $B$. plicatilis were identified according their size. The individuals were separately extracted and cultured, but only the populations of the biggest type had a suitable growth (196 $\mu \mathrm{m}$ average lorica length). The strain was named Bprs01 until its molecular identification. All the cultures were maintained in low densities to avoid sexual reproduction. The clonal lines were established from a single female and maintained in different flasks for several months. During the phase of acclimation to laboratory conditions, the multiclonal populations established similarly to those described by Gabaldón et al. (2015) were cultivated in 500$\mathrm{ml}$ Erlenmeyer flasks under stable physical and chemical conditions similar to those measured in the field at the time of sampling (i.e., temperature, $24 \pm 1{ }^{\circ} \mathrm{C}$; conductivity, $5.0 \mathrm{mS} . \mathrm{cm}^{-1}$; photoperiod 14:10), for a period of two generations (i.e., 15 days; Cabrera 2008). During the experimental phase the conductivity was produced by dissolving $\mathrm{NaCl}$ in the culture medium. This salt was chosen after having performed a previous experiment where the population growth of $B$. plicatilis did not manifest significant differences between the use of $\mathrm{NaCl}$ and a sea-salt mixture. The counting and sorting of the individuals were done under a stereoscopic microscope (Olympus SZ61) for removal of the females with 1-mL Pasteur pipettes for separate cultivation. The rotifers were fed with the unicellular chlorophyte Chlorella vulgaris at densities of $2 \times 10^{6}$ ind. $\mathrm{mL}^{-1}$ every three days to maintain the feeding ad libitum (Cabrera 2008). This alga, besides being a palatable food for these rotifers, has the advantage of being tolerant and adaptable to conductivity changes (Vallejo et al. 1993). Its plasticity makes the species an ideal food for this type of experiment through maintaining an adequate physiologic maintenance during all the experimental treatments, and in so doing, having no negative influence on the rotifers' nutrition. The alga was also cultured in the laboratory in 1.8-L transparent flasks in Bold's basal medium (Borowitzka and Borowitzka 1988), and daily monitored with a laboratory turbidimeter (2100P Hach) (Ferrando et al. 2015). The density of $C$. vulgaris for the experimental phase was established by counting in a hemocytometer.

\section{CONDUCTIVITY EXPERIMENT}

The conductivity experiment was carried out in an incubation chamber where 36 Nessler tubesrepresenting nine conductivities (including the control group at $5 \mathrm{mS} . \mathrm{cm}^{-1}$ ) in four experimental replicates-were placed, each containing $30 \mathrm{ml}$ of EPA culture medium (Anonymous 1985). The experiments-performed in quadruplicate, with the data being compared to the control conductivity of $5 \mathrm{mS} . \mathrm{cm}^{-1}$ corresponding to the average value measured in the field at the time of sample collection-involved four treatments with decreasing conductivities of $4,3,2$, and $1 \mathrm{mS} \mathrm{cm}^{-1}$ and four treatments with increasing values of 8 , 11,15 , and $17 \mathrm{mS} \cdot \mathrm{cm}^{-1}$. The initial amount of nonovigerous females inoculated was 2 ind. $\mathrm{mL}^{-1}$ (60 individuals per tube). The temperature and $\mathrm{pH}$ of the water were monitored before each rotifer count, and the volume of evaporated water was restored with distilled water to maintain the total volume constant. The density of the rotifers (in ind. 
$\mathrm{mL}^{-1}$ ) was calculated after making daily counts of the entire volume under a stereoscopic microscope (Olympus SZ61).

The adult ovigerous females along with the number of asexual eggs they carried were counted separately from the nonovigerous. The number of diapausing eggs present was also determined.

\section{TEMPERATURE EXPERIMENT}

The historical average air temperature (from 1933 to the present) at the different sampling sites in the Buenos Aires province where the strain of $B$. plicatilis was obtained fluctuates between $15^{\circ} \mathrm{C}$ in autumn and spring and $25{ }^{\circ} \mathrm{C}$ in summer (Http:// data.giss.nasa.gov/tmp/gistemp/STATIONS/). The conductivity value $\left(5 \mathrm{mS} . \mathrm{cm}^{-1}\right)$ reflects the mean of records obtained in the Salado River basin during the last decades (Gabellone et al. 2008). The temperature experiment was carried out in incubators set at those two contrasting temperatures and at the average conductivity (5 $\left.\mathrm{mS} . \mathrm{cm}^{-1}\right)$. Sixteen glass vials were filled with 20 $\mathrm{ml}$ of EPA culture medium and inoculated with 0.5 x $10^{6}$ ind. $\mathrm{mL}^{-1}$ of Chlorella vulgaris. The initial rotifer density for all the groups was 10 individuals per vial (i.e., 0.5 ind. $\mathrm{mL}^{-1}$ ). All treatments were performed with four biological replicates. Half of the vials were inoculated with adult nonovigerous females for the population-growth experiments, with rotifer counts being made every $24 \mathrm{~h}$; while the other half were inoculated with neonates for the life-table experiments, with counting in that group every $12 \mathrm{~h}$. In this instance, the dead individuals and live neonates were removed after counting, and the surviving individuals of the original cohort were transferred to fresh medium. For these life-table studies, the experiment was concluded at the moment when all the females of the original cohort had died. The populationgrowth rate $(r)$ and the duplication time $(d t)$ were calculated in the population-growth experiments.
The gross and net reproductive rate, survival rate, and fecundity rate were calculated with the data obtained from the life table for each treatment. At the end of the experiment, the total volume of each experimental group was fixed with $4 \%(\mathrm{v} / \mathrm{v})$ aqueous formaldehyde for subsequent observation under an optical microscope (Olympus CX31). The corresponding morphometric measurements were recorded (body length and width) and the biovolume calculated and transformed to biomass separately for the individuals from each treatment according to McCauley (1984).

\section{STATISTICAL ANALYSIS}

A repeated-measurement analysis of variance (RM ANOVA) was carried out to analyze the effects of salinity on the total density and ovigerous female density through time, and the effect of the temperature on the total density through time (Balzarini et al. 2008). A one-way ANOVA was performed to analyze the effects of salinity on the rate of population increase $(r)$, the peak of population density, the average biomass of the amictic females, the temperature effects on the rate of population increase $(r)$, and the gross and net reproductive rate. A t-Student test was performed to compare the mean values between ovigerous and nonovigerous biomass and for the total biomass in the two temperatures tested (Montgomery 2013).

The assumptions for each calculationhomogeneity of variances by Levene's test for the one-way ANOVA and, for the repeated-measures (RM) ANOVA, sphericity by the Mauchley testwere considered. A posteriori multiple comparison among means was performed by the Fisher LSD post-hoc test, only for those analysis having statistically significant results. All the analysis were performed with the statistical software Infostat $\mathrm{v}$ 2016 (Di Rienzo et al 2016). 


\section{RESULTS}

\section{CONDUCTIVITY}

The population growth exhibited a marked overlap among the different conductivities during the first week of the experiment. The population density at the lowest conductivity $\left(1 \mathrm{mS} . \mathrm{cm}^{-1}\right)$ was the first to depart from the control values (Fig. 1). Differences in the population density through time were statistically significant (RM ANOVA $p$ $<0.001)$ between the treatments during the entire period of the experiment (Table I). The highest population density recorded was obtained at a conductivity of $5 \mathrm{mS} . \mathrm{cm}^{-1}\left(37.3\right.$ ind. $\left.\mathrm{mL}^{-1}\right)$, while the lowest conductivity $\left(1 \mathrm{mS} . \mathrm{cm}^{-1}\right)$ produced a clear decrease in that parameter (at $<3$ ind. $\mathrm{mL}^{-1}$ ) at that time. The peak of population density was observed at day 12 for all treatments except for the lowest conductivity $\left(1 \mathrm{mS} \cdot \mathrm{cm}^{-1}\right.$, day 8$)$. This parameter exhibited statistical differences between treatments $(\mathrm{p}<0.001$, Table I), showing the minor density value at the lowest conductivity. In addition, two homogeneous groups (referred statistically to treatments without significant differences between them) were presented: one with the treatments $(2$, 3, 4 and $17 \mathrm{mS} . \mathrm{cm}^{-1}$ ) where the lowest density values were recorded, and the other $(5,8,11$ and $14 \mathrm{mS} . \mathrm{cm}^{-1}$ ) with the highest values (Fig. 2a). The densities of the ovigerous females within the experimental populations remained at mean values corresponding to approximately $8 \pm 2 \%$ of the total densities among the groups, with these individuals growth exhibiting a behavior comparable to the rest of the rotifers under the majority of the experimental conditions (Table I). The extremes in conductivity (i.e., 1 and $17 \mathrm{mS} . \mathrm{cm}^{-1}$ ), however, resulted in the lowest density of ovigerous females.

The presence of males, diapausing eggs, amictic females, and certain females with deformed loricas were observed at the three levels of lower

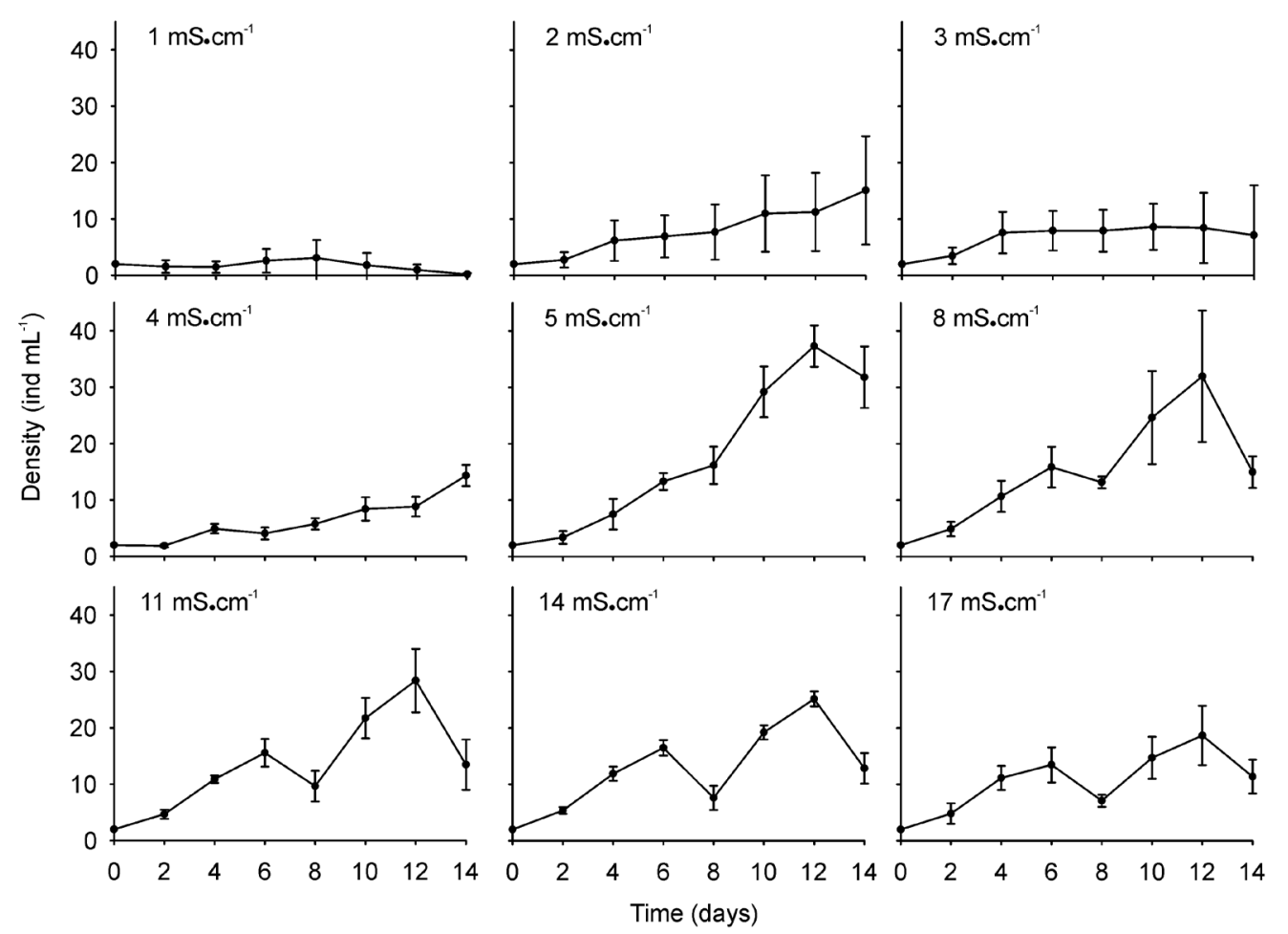

Figure 1 - Population growth of Brachionus plicatilis at different conductivities $\left(1-17 \mathrm{mS} . \mathrm{cm}^{-1}\right)$. Mean values \pm standard error are shown based on four biological replicates. 
TABLE I

Statistical evaluation by the RM-ANOVA of the total population and ovigerous-female densities of Brachionus plicatilis and by the one-way ANOVA of the rate of population increase, the peak of population density and the biomass of the rotifer cultured at different conductivities $(\mathrm{DF}=$ degrees of freedom, $\mathrm{SS}=$ sum of the squares, $\mathrm{MS}=$ mean $\mathrm{square}, \mathrm{F}=$ F-ratio, $\mathbf{p}=\mathbf{p}$ value).

\begin{tabular}{|c|c|c|c|c|c|}
\hline & DF & SS & MS & $\mathbf{F}$ & $\mathbf{p}$ \\
\hline \multicolumn{6}{|l|}{ Population density } \\
\hline Conductivity (A) & 8 & 6278.07 & 784.76 & 15.12 & 0.0000 \\
\hline Time (B) & 7 & 8391.22 & 1198.75 & 160.34 & 0.0000 \\
\hline A B interaction & 56 & 5262.71 & 93.98 & 12.57 & 0.0000 \\
\hline Error & 189 & 1412.99 & 7.48 & & \\
\hline \multicolumn{6}{|l|}{ Ovigerous females } \\
\hline Conductivity (A) & 8 & 10.55 & 1.32 & 3.59 & 0.0059 \\
\hline Time (B) & 6 & 5.26 & 0.87 & 15.784 & 0.0000 \\
\hline A B interaction & 48 & 7.60 & 0.15 & 2.84 & 0.0000 \\
\hline Error & 162 & 9.01 & 0.05 & & \\
\hline \multicolumn{6}{|c|}{ Rate of population increase $(r)$} \\
\hline Conductivity & 8 & 0.39 & 0.04 & 15.29 & 0.0000 \\
\hline Error & 27 & 0.09 & 0.003 & & \\
\hline \multicolumn{6}{|c|}{ Peak of population density } \\
\hline Conductivity & 8 & 4676.58 & 584.57 & 17.24 & 0.0000 \\
\hline Error & 27 & 915.29 & 33.9 & & \\
\hline \multicolumn{6}{|c|}{ Amictic females biomass } \\
\hline Conductivity & 8 & 0.0339 & 0.0043 & 8.6 & 0.0000 \\
\hline Error & 157 & 0.0775 & 0.0005 & & \\
\hline
\end{tabular}

conductivity (i.e., 1 to $3 \mathrm{mS} . \mathrm{cm}^{-1}$ ) as well as at the two of higher conductivities (i.e., 14 and 17 $\mathrm{mS} . \mathrm{cm}^{-1}$ ) by the end of the experiment.

The rate of population growth $(r)$ was statistically different in response to conductivity (Table I). The conductivity that produced the highest growth rate was the control level of 5 $\mathrm{mS} . \mathrm{cm}^{-1}$, with an average $r$ value of 0.26 and a maximum of 0.32 (Fig. 2a) along with an average duplication time $(d t)$ of 3.11 days. A conductivity of $3 \mathrm{mS} . \mathrm{cm}^{-1}$ resulted in the lowest values $(r$ average $=0.10$ ) corresponding to a higher $d t$ of 7.6 days. Conductivities of 2,4 , and $17 \mathrm{mS} \cdot \mathrm{cm}^{-1}$ also were associated with lower growth rates $\left(r_{\text {average }}=0.11\right.$, 0.12 , and 0.18 , respectively) than the control values and a $d t$ that almost doubled that of the controls (i.e., 5.6 vs. 4.8 days). The conductivities of 8,

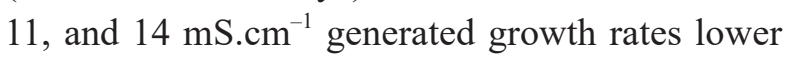

than but near to those of the controls $(r \underset{\text { average }}{=}$ 0.21 and 0.22 ). Finally, the greatest decrease in the population density occurred at the lowest conductivity $\left(1 \mathrm{mS} . \mathrm{cm}^{-1}\right)$, with that level producing a negative population-growth rate $\left(r_{\text {average }}=-0.10\right.$; $r_{\max }=-0.19$ ).

As to the morphometry measurements, the respective mean values for the body length and width for the nonovigerous females were $189 \pm 5$ and $139 \pm 4 \mu \mathrm{m}$ and the corresponding maximum values 197 and $179 \mu \mathrm{m}$, while the average body length of the ovigerous females was lower at 187 $\pm 5 \mu \mathrm{m}$. The respective average length and width of the parthenogenetic eggs were $102 \pm 5 \mu \mathrm{m}$ and $81 \pm 8 \mu \mathrm{m}$.

The lowest conductivities of 1 to $4 \mathrm{mS} . \mathrm{cm}^{-1}$ produced higher average biomasses than did the other five levels, including the control $\left(\mathrm{F}_{8,157}=8.6 ; \mathrm{p}\right.$ 

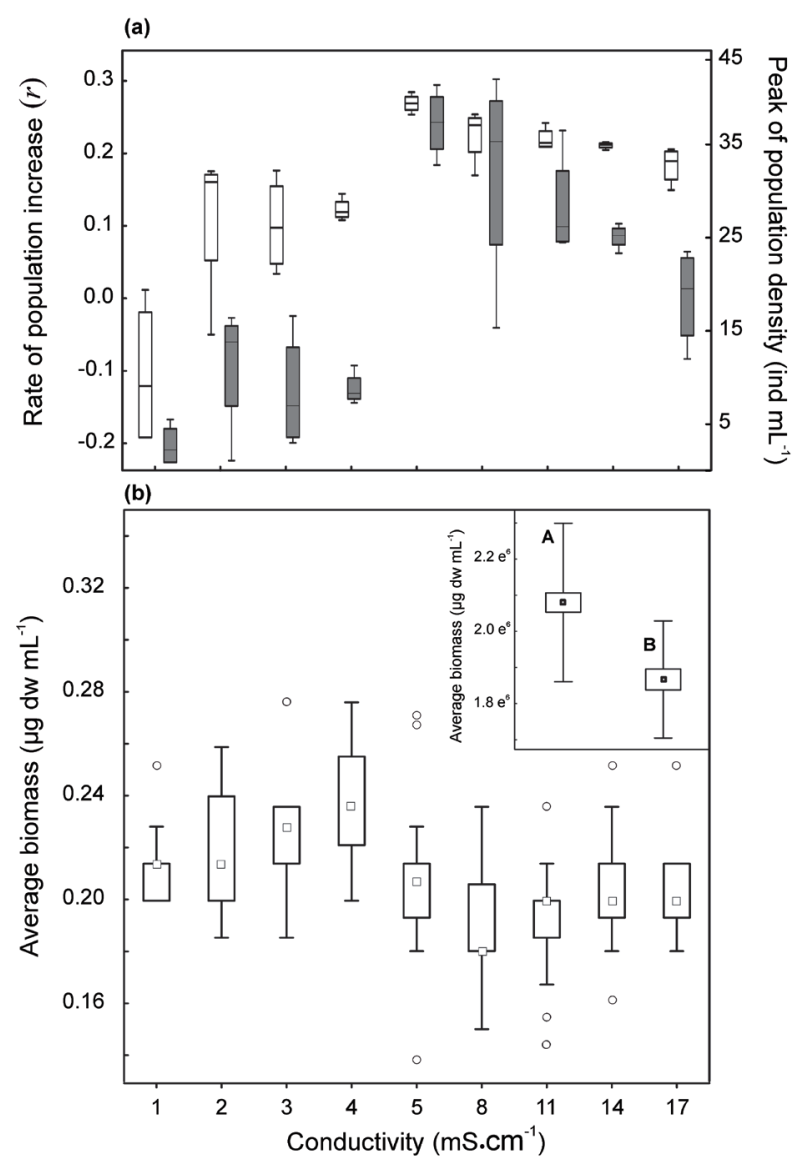

Figure 2 - (a) Box plots of the rate of population increase of Brachionus plicatilis at the peak of population growth (day 12) in all the conductivity treatments (white boxes) and the peak of population density (grey boxes). (b) Box plots of the average biomass of Brachionus plicatilis amictic females at each conductivity level by the end of the experiment. The inset indicates the differences between $(\mathbf{A})$ nonovigerous and $(\mathbf{B})$ ovigerous females. Figure indications relative to the median value: box, $25 \%-75 \%$; whiskers, maximum and minimum values within $95 \%$ of the distribution; and points, outliers.

$<0.001$; Fig. 2b). The biomass of the nonovigerous females, moreover, was significantly higher than that of the ovigerous females $(\mathrm{t}=4.47, \mathrm{p}<0.001$; Fig. 2b inset).

\section{TEMPERATURE}

Differences in the population structure for each temperature were evidenced from the experiment inoculated with the neonates (Fig. 3). The greatest difference was found between the neonate densities at the two temperatures, where the maximum values were 17 ind. $\mathrm{mL}^{-1}$ on day 2 at $25^{\circ} \mathrm{C}$ versus 4 ind. $\mathrm{mL}^{-1}$ between days 4 to 6 at $15^{\circ} \mathrm{C}$. In contrast, the egg densities at the two temperatures were quite similar, with those maxima being 16 to 17 per day. The egg production at $25^{\circ} \mathrm{C}$ began very early on Day 1 , whereas at $15^{\circ} \mathrm{C}$ an equivalent production was reached only by days 3 to 4 . The adults behaved quite comparably at the two temperatures during the days following inoculation and began to die between days 5 and 6 .

The percentage of hatched eggs and the egg ratio (Fig. 4a, b, respectively) exhibited clear differences between the two treatments. Ratios of 2.2 eggs per female were found at $15{ }^{\circ} \mathrm{C}$ as opposed to only 1.8 at $25^{\circ} \mathrm{C}$; but an analysis of the percentage of hatched eggs revealed that at $25^{\circ} \mathrm{C}$ extremely high values were attained on the days of maximum production, reaching even $100 \%$ on Day 2 and thereafter maintaining levels of $80-95 \%$ on subsequent days. In contrast, at $15^{\circ} \mathrm{C}$ the sole peak in the percentage of hatched eggs occurred on Day 2 , when the egg production was very low at $5 \%$ eggs per female.

This relationship became inverse during the following days, where a markedly increased egg production resulted in much lower levels of hatching, ranging between 13 and $37 \%$ at less than a half the hatching observed at the highest temperature or at the previous peak on Day 2.

Survival values remained quite comparable between the two temperatures, though became slightly lower at $25{ }^{\circ} \mathrm{C}$ as of the fourth day (Fig. $\left.4 \mathrm{c} ; \mathrm{F}_{1,4}=0.83 ; \mathrm{p}>0.05\right)$. With time, a significant decrease in this parameter occurred $\left(\mathrm{F}_{10,40}=111.81\right.$; $\mathrm{p}<0.001$ ), but that pattern was comparable at the two temperatures. With respect to fecundity, the differences were significant $(\mathrm{p}<0.001)$ for the interaction $\left(\mathrm{F}_{10,40}=15.22\right)$ between the parameters of time and temperature $\left(\mathrm{F}_{10,40}=26.75\right.$ and $\mathrm{F}_{1,4}$ $=179.88$ respectively). With the exception of Day 1 (and also the initial and final days), the 


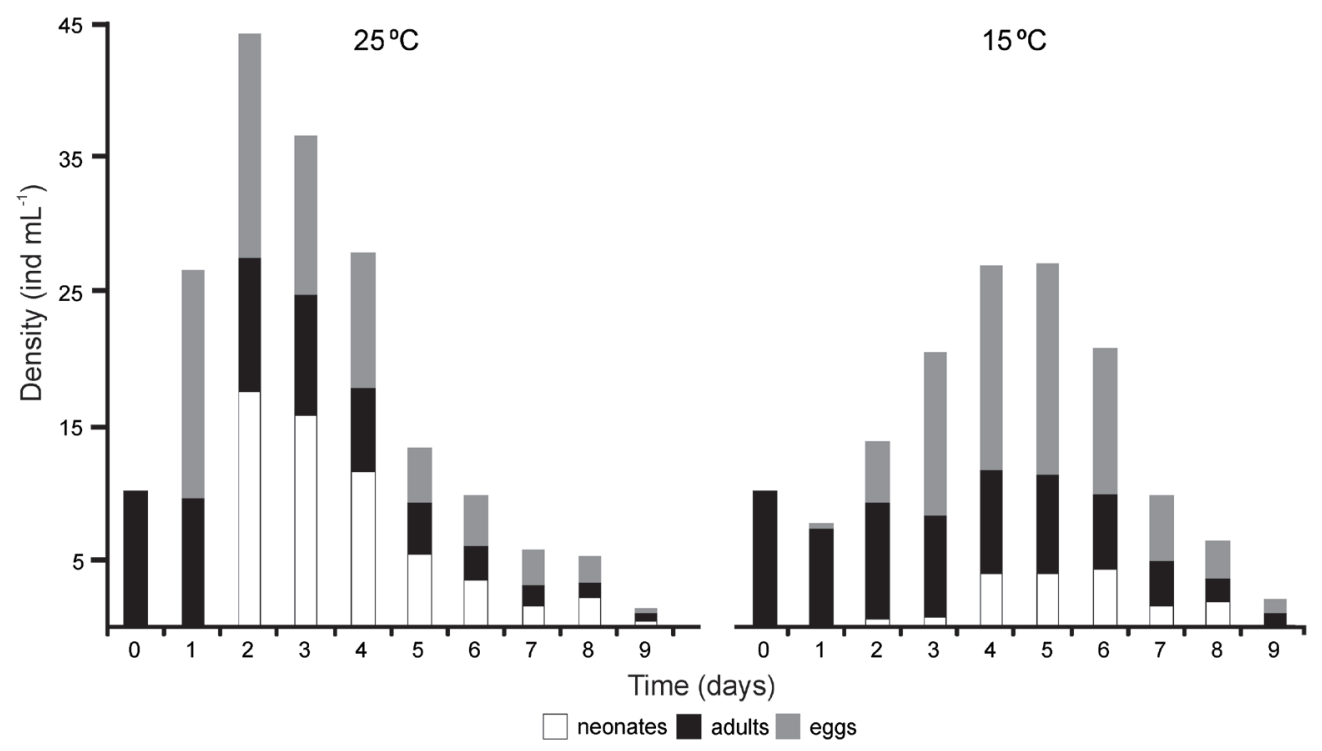

Figure 3 - Population structure of Brachionus plicatilis with respect to the density of eggs, adults, and neonates at temperatures of 25 and $15^{\circ} \mathrm{C}$.
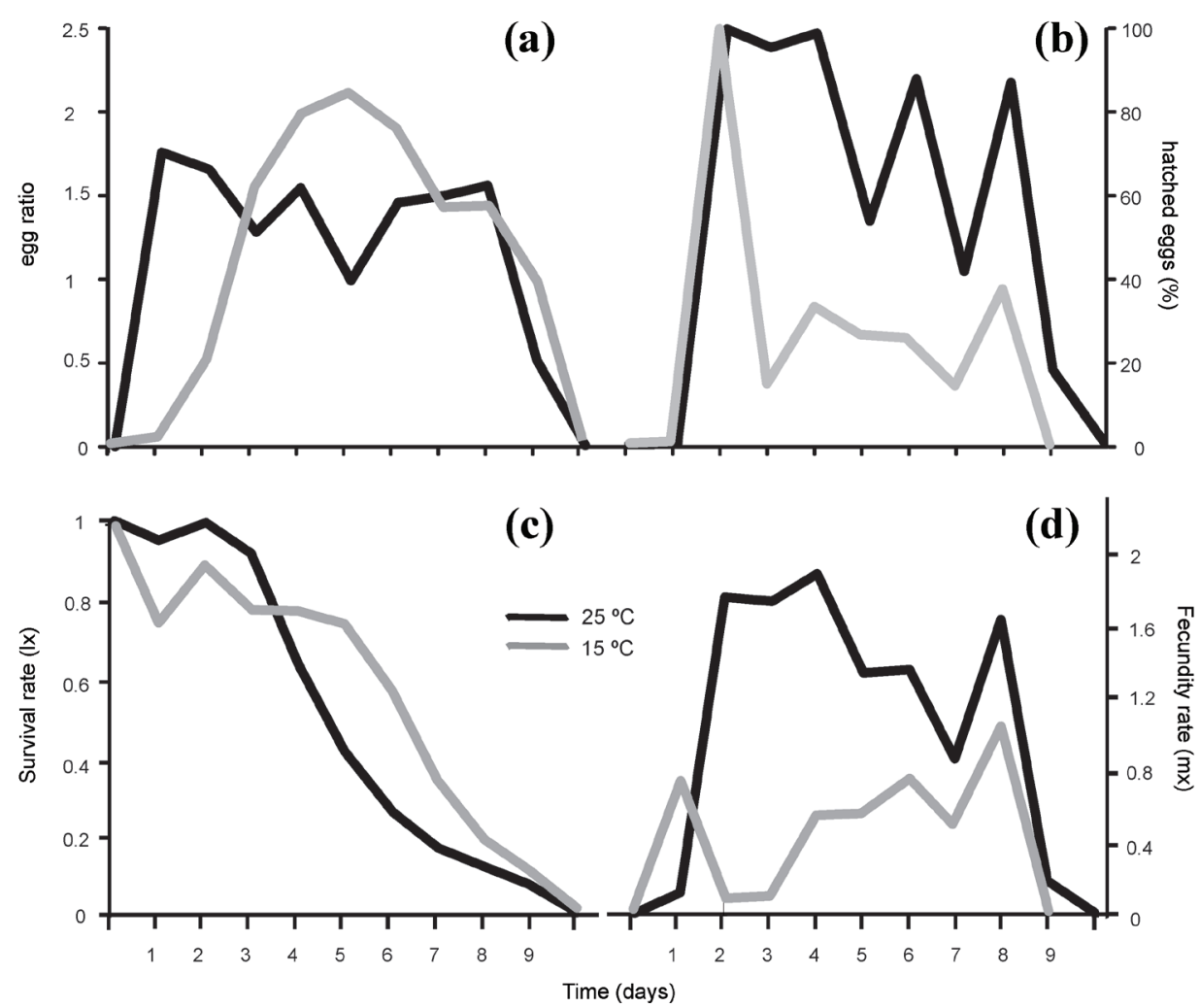

Figure 4 - Comparison between the egg ratio (a) and the percentage of hatched eggs per day (b), and for the survival rate (c) and the fecundity (d) of Brachionus plicatilis between the two temperatures tested: $25^{\circ} \mathrm{C}$ (black curves) and $15^{\circ} \mathrm{C}$ (gray curves). 
values at $25{ }^{\circ} \mathrm{C}$ were always higher, with the maximum dissimilarity in the parameter at the two temperatures occurring from days 2 to 6 (Fig 4d). The highest fertility was found on days 2 through 4 at $25{ }^{\circ} \mathrm{C}$, while a slightly smaller peak was present near the end of the experiment on Day 8 . On that day, the highest average fertility value was recorded at $15^{\circ} \mathrm{C}(1.0 \pm 0.3)$. Statistical differences were found between the two temperatures for the population-growth rate $(r)$, the gross reproductive rate (GRR), and the net reproductive rate (NRR) (Table II). The LSD-posteriori test indicated that for all three variables the mean values were always significantly lower at the temperature of $15^{\circ} \mathrm{C}$ (Fig. 5).

The largest individuals were found at $15^{\circ} \mathrm{C}$ with an average length of $235 \mu \mathrm{m}$ and a maximum of $247 \mu \mathrm{m}$. At $25{ }^{\circ} \mathrm{C}$ the average-sized rotifers at $196 \mu \mathrm{m}$ were $17 \%$ smaller, while the largest at $226 \mu \mathrm{m}$ were $9 \%$ smaller. The values of biomass ( $\mu \mathrm{g}$ dry weight) were likewise different between the two temperatures $(\mathrm{t}=-4.59, \mathrm{p}<0.001)$ at an average biomass of $0.40 \mu \mathrm{g}$ (maximum $=0.46 \mu \mathrm{g}$ ) at $15{ }^{\circ} \mathrm{C}$ and one at $0.26 \mu \mathrm{g}$ (maximum $=0.39 \mu \mathrm{g}$ ) at $25^{\circ} \mathrm{C}$.

\section{DISCUSSION}

The overlap in the population growth in all treatments during the first 8 days can be explained by the characteristic latent period needed for the acclimation of a population to a specific environmental condition (Pascual and Yúfera 1983). Accordingly, during this first week, similar densities were recorded for the previously acclimated females (control) and for those that were incorporated during the days after the initial inoculation, though the two subpopulations were born at different conductivities. Pascual and Yúfera (1983) cited that the populations of B. plicatilis grow very well after being transferred directly to different conductivities, though they specified an increase in the latent period as a consequence. The presence of mictic females was not recorded in the first generation in agreement with what had been observed by Hagiwara and Hino (1989) since the age of the female progenitor is a determinant of the production of this type of female (Kim and Hagiwara 2011).

The difference found in the female biomass could be related to the so-called Lansing effect (Gribble et al. 2014)-indicating that older females in cultures will transmit a signal to their offspring so that the following generations begin to reproduce earlier. Consequently that the next generations will have a smaller size because the energy stores will be diverted to reproduction. This phenomenon could have occurred in our experiment since the protocol was designed with an initial inoculum of nonovigerous adult females of similar sizes. Therefore, in the present situation, the ovigerous females measured at the end of the experiment representing the smallest size may be the offspring of the original inoculants.

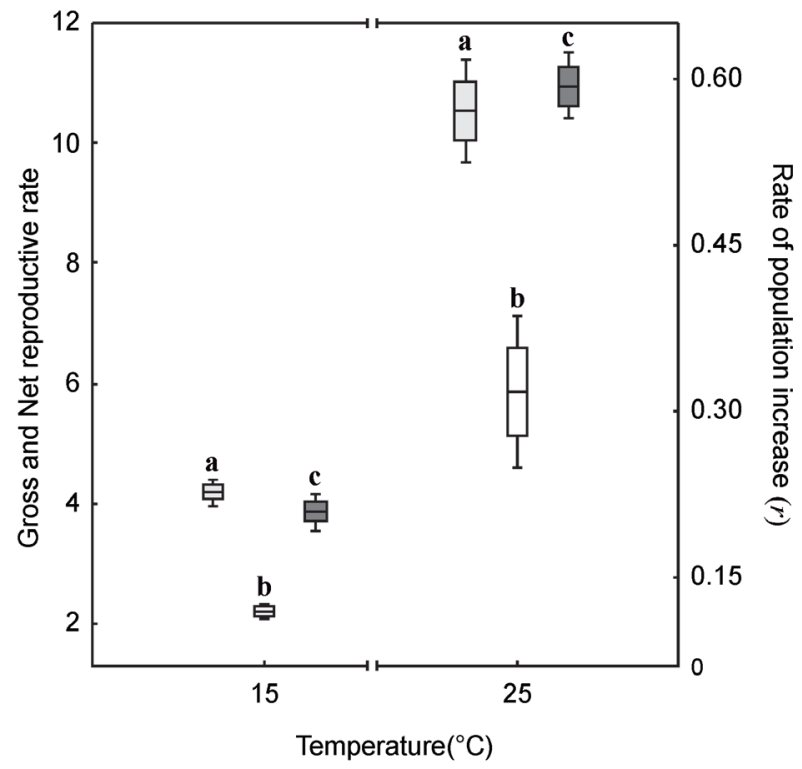

Figure 5 - Box plots of gross (a) and net (b) reproductive rate, and rate of population increase (c) of Brachionus plicatilis at 15 and $25{ }^{\circ} \mathrm{C}$. Figure indications relative to the median value: box, 25\%-75\%; whiskers, maximum and minimum values within $95 \%$ of the distribution; and points, outliers. 
TABLE II

Statistical evaluation by RM ANOVA of the population density of Brachionus plicatilis and by one-way ANOVA of the gross and net reproduction rates and the rate of increase in the population of Brachionus plicatilis at different temperatures (DF = degrees of freedom, $\mathrm{SS}=$ sum of the squares, $\mathrm{MS}=$ mean square, $\mathrm{F}=\mathrm{F}$-ratio, $\mathrm{p}=\mathrm{p}$-value).

\begin{tabular}{|c|c|c|c|c|c|}
\hline & DF & SS & MS & $\mathbf{F}$ & $\mathbf{p}$ \\
\hline \multicolumn{6}{|l|}{ Population density } \\
\hline Temperature (A) & 1 & 97219.6 & 97219.6 & 439.9 & 0.000006 \\
\hline Time (B) & 14 & 151622.7 & 10830.2 & 69.21 & 0.000031 \\
\hline A B interaction & 14 & 111522.7 & 7965.9 & 50.9 & 0.000000 \\
\hline Error & 56 & 8763.5 & 156.5 & & \\
\hline \multicolumn{6}{|c|}{ Rate of population increase $(r)$} \\
\hline Temperature & 1 & 0.22 & 0.22 & 379.27 & 0.000000 \\
\hline Error & 4 & 0.002 & 0.0005 & & \\
\hline \multicolumn{6}{|c|}{ Gross reproductive rate } \\
\hline Temperature & 1 & 60.83 & 60.83 & 159.5 & 0.000000 \\
\hline Error & 4 & 1.52 & 0.38 & & \\
\hline \multicolumn{6}{|l|}{ Net reproductive rate } \\
\hline Temperature & 1 & 19.98 & 19.98 & 24.82 & 0.000000 \\
\hline Error & 4 & 3.22 & 0.8 & & \\
\hline
\end{tabular}

We recorded asexual reproduction rates at the intermediate conductivities in this experiment, indicating that the populations had developed within a favorable environment (Lubzens et al. 1985). This observation is consistent with the findings of several authors demonstrating a direct effect of salinity on growth rates that depended on the species and genotype in question (Miracle and Serra 1989, Serra et al. 1998). Each genotype will thus become adapted to an optimal salinity in which the growth rate will be maximum (Anitha and George 2006); hence the relevance and significance of determining the specific $r$ for each genotype under consideration. We agree with Gabaldón et al. (2016) that the production of diapausing eggs at lower conductivities produces a decrease of its rate of asexual proliferation, although they observed this situation at higher conductivities than those tested here.

The $r$ values obtained in our experiments are similar to those reported by Malekzadeh Viayeh et al. (2010) for four Iranian strains fed the same food as in the present experiments, whereas the population-density peaks of our strain were notably lower than those attained by the Iranian rotifers. The maximum $r$ value of our strain of $B$. plicatilis at the optimal conductivity was similar to the one reported by Montero-Pau et al (2011) in Iberian salt lakes at higher conductivities. Notwithstanding, the life-spans obtained at the different conductivities in the present work were similar to those recorded by Hagiwara and Hino (1990).

Within the conductivity range investigated, the lowest limit of tolerance was between levels of 1 and $2 \mathrm{mS} . \mathrm{cm}^{-1}$, which values are in agreement with the observation of Pascual and Yúfera (1983) in salinity experiments with this same species. The differences between these results and those obtained at higher salinities by a sizeable number of authors ( $c f$. Lubzens 1985, among others) can be attributed to the genetic variation in the strains that reflect the ecologic requirements for a given geographical area (Vallejo et al. 1993).

Our results on the influence of temperature are in agreement with those reported by Miracle and Serra (1989) and Yin and Zhao (2008) with different 
strains indicating that the maximum growth is achieved at temperatures between 24 and $30^{\circ} \mathrm{C}$. The pampean strain of $B$. plicatilis population growth was significantly different at both temperatures and these results disagreed with those obtained with a Spain strain by Walczyńska and Serra (2014) and Walczyńska et al. (2017). These authors concluded that the eurioic $B$. plicatilis is exposed to a high variability of temperature in the environments where the species live acquiring a significant plasticity, and thus, can maintain a steady growth in these circumstances. We observed that females at lower temperatures produced fewer offspring per day, but remained reproductive longer, similar to the results obtained by Johnston and Snell (2016).

An inverse relation between the adults' size and the temperature was detected in our experiments, and the same phenomenon was observed by Walczyńska et al. (2017).

The present findings confirm that populations of a local strain can reach high densities, mainly in the spring and summer periods, in the lotic environments of the Salado River basin; as previously documented by Claps et al. (2009), where both the lowest and optimum conductivity limits were similar to those observed in the experiments reported here. The same circumstance was noted by José de Paggi and Paggi (1998) for the Salado River and the Juan de Garay Lake in the Santa Fe province, where the authors found B. plicatilis as the dominant species at the highest conductivities recorded $\left(3.5 \mathrm{mS} . \mathrm{cm}^{-1}\right.$ for the lake and $6.3 \mathrm{mS} . \mathrm{cm}^{-1}$ for the river). In most of the pampean shallow lakes, normally characterized by conductivity values lower than $1 \mathrm{mS} . \mathrm{cm}^{-1}$, the presence of $B$. plicatilis is only possible during the summer months when the hydrometric level effectively decreases so as to raise the conductivity to values exceeding $2 \mathrm{mS} . \mathrm{cm}^{-1}$ as the result of minimal rainfall and maximal evaporation (Ardohain et al. 2005, Claps et al. 2011). As Johnston and Snell (2016) exposed, the response of rotifer strains to low temperature treatments could be explained as an ecological specialization and temperature adaptation between closely related species (B. plicatilis, B. manjavacas and B. calyciflorus).

Conductivities between 1 and 3 and between 14 and $17 \mathrm{mS} . \mathrm{cm}^{-1}$ could be considered quite unfavorable for the growth of this rotifer strain because, despite the favorable environment in terms of food and temperature in the experiments at those salinities, we observed the presence of males and the greatest production of resting eggs (Hagiwara and Hino 1989). At the remaining conductivities, these members of the population were not observed during the entire experiment despite the high density otherwise recorded, so that their presence could be considered a triggering condition for the production of mictic females (Stelzer and Snell 2003). Such a scenario would suggest that the population had not reached a critical density.

Our results indicate that the optimal settlement in the typical freshwater environments of this relevant and perennial member of zooplankton community in pampean saline environments would be possible only under circumstances of increased temperatures and salinities related to seasonal and/ or climatic changes. Under normal conductivity conditions, the resting eggs remain inactive in the lake sediments. The likelihood of this colonization is related to the presence of B. plicatilis eggs in the sediments of those environments that could hatch under conditions of conductivity only slightly higher than the lowest ones examined here. For this reason, in any propitious season, the dominance of the populations of $B$. plicatilis will be promoted within the zooplankton community along with a potential disappearance of other rotifer species.

\section{ACKNOWLEDGMENTS}

This work was funded by Agencia Nacional de Promoción Científica y Tecnológica (ANPCyT) (PICT 2012-0228) and Universidad Nacional 
de La Plata (UNLP) (N737). Noelia S. Ferrando was supported by a postdoctoral fellowship from the CONICET. Dr. Donald F. Haggerty, a retired academic career investigator and native English speaker, edited the final version of the manuscript. We are grateful to the reviewers for the careful reading of our manuscript and the constructive and valuable comments. Scientific Contribution $\mathrm{N}^{\circ} 1008$ of the Institute of Limnology Dr. Raúl A. Ringuelet (ILPLA, CONICET, UNLP).

\section{REFERENCES}

ANITHA PS AND GEORGE RM. 2006. The taxonomy of Brachionus plicatilis species complex (Rotifera: Monogononta) from the Southern Kerala (India) with a note on their reproductive preferences. J Mar Biol Ass India 48: 6-13.

ARDOHAIN D, BENÍTEZ H, CLAPS M AND GABELLONE N. 2005. Estructura y dinámica de rotíferos planctónicos en dos lagunas pampásicas: similitudes y diferencias. Biol Acuat 22: 7-18.

BALZARINI MG, GONZALEZ L, TABLADA M, CASANOVES F, DI RIENZO JA AND ROBLEDO CW. 2008. Infostat. Manual del Usuario, Editorial Brujas, Córdoba, Argentina, 334 p.

BAZZURI ME. 2016. Estudio de la comunidad planctónica en relación con las modificaciones antrópicas de la red de drenaje de la cuenca del río Salado (Bs. As.). Tesis Doctoral Facultad de Ciencias Naturales y Museo, Universidad Nacional de La Plata, 314 p.

BOROWITZKA MA AND BOROWITZKA LJ. 1988. Microalgal Biotechnology, London: Cambridge University Press, $466 \mathrm{p}$.

CABRERA MI. 2008. Tasa de crecimiento poblacional del rotífero Brachionus rotundiformis (Rotifera: Brachionidae) en un quimiostato de dos cámaras. Rev Biol Trop 56: 1149-1157.

CABRERA T, BAE JH, BAI SC AND HUR SB. 2005. Effects of microalgae and salinity on the growth of three types of the rotifer Brachionus plicatilis. Fish Aquatic Sci 8: 70-75.

CHENG SH, KÂ S, KUMAR R, KUO CS AND HWANG JS. 2011. Effects of salinity, food level, and the presence of microcrustacean zooplankters on the population dynamics of rotifer Brachionus rotundiformis. Hydrobiologia 666: 289-299.

CLAPS M, GABELLONE N AND NESCHUK N. 2009. Influence of regional factors on zooplankton structure in a saline lowland river: the Salado River (Buenos Aires province, Argentina). River Res Applic 25: 453-471.
CLAPS MC, GABELLONE NA AND BENÍTEZ HH. 2011. Seasonal changes in the vertical distribution of rotifers in a eutrophic shallow lake with contrasting states of clear and turbid water. Zool Stud 50: 454-465.

DI RIENZO JA, CASANOVES F, BALZARINI MG, GONZALEZ L, TABLADA M AND ROBLEDO CW. 2016. InfoStat versión 2016. Grupo InfoStat, FCA, Universidad Nacional de Córdoba, Argentina. URL http:// www.infostat.com.ar.

ECHANIZ SA, CABRERA GC, RODRÍGUEZ C AND VIGNATTI AM. 2013. Do temporary lakes vary from year to year? A comparison of limnological parameters and zooplankton from two consecutive annual cycles in an Argentine temporary saline lake. Internat $\mathrm{J}$ Aquat $\mathrm{Sc}$ 4: 44-61.

ECHANIZ SA, VIGNATTI AM, DE PAGGI, SJ, PAGGI JC AND PILATI A. 2006. Zooplankton seasonal abundance of South American saline shallow lakes. Internat Rev Hydrobiol 91: 86-100.

FERRANDO NS, BENÍTEZ HH, GABELLONE NA, CLAPS MC AND ALTAMIRANO PR. 2015. A quick and effective estimation of algal density by turbidimetry developed with Chlorella vulgaris cultures. Limnetica 34: 397-406.

FERRANDO NS AND CLAPS MC. 2016. A revised and updated checklist of Monogononta rotifers from Argentina. Check List 12: 1942.

FIELDER DS, PURSER GJ AND BATTAGLENE SC. 2000. Effect of rapid changes in temperature and salinity on availability of the rotifers Brachionus rotundiformis and Brachionus plicatilis. Aquaculture 189: 85-99.

GABALDÓN C, FONTANETO D, CARMONA MJ, MONTERO-PAU J AND SERRA M. 2016. Ecological differentiation in cryptic rotifer species: what we can learn from the B. plicatilis complex. Hydrobiologia 796: 7-18.

GABALDÓN C, SERRA M, CARMONA MJ AND MONTERO-PAU J. 2015. Life-history traits, abiotic environment and coexistence: The case of two cryptic rotifer species. J Exp Mar Biol Ecol 465: 142-152.

GABELLONE N, SOLARI LC, CASCO MA AND CLAPS MC. 2013. Conservación del plancton y protección de las cuencas hídricas. El caso de la Cuenca Inferior del Río del Salado, Provincia de Buenos Aires, Argentina. Augmdomus 5: 100-119.

GABELLONE NA, CLAPS MC, ARDOHAIN DM, DIPPOLITO A, BAZZURI ME AND SOLARI LC. 2014. Relationship between the zoo-and phytoplankton biomasses in a saline lowland river (Argentina): a shorttime-scale analysis. Fundam Appl Limnol 184: 307-327.

GABELLONE NA, SOLARI L, CLAPS M AND NESCHUK N. 2008. Chemical classification of the water in a lowland river basin (Salado River, Buenos Aires, Argentina) affected by hydraulic modifications. Environ Geol 53: 1353-1363. 
GÓMEZ A, SERRA M, CARVALHO GR AND LUNT DH. 2002. Speciation in Ancient Cryptic Species Complexes: Evidence from the Molecular Phylogeny of Brachionus plicatilis (Rotifera). Evolution 56: 1431-1444.

GRIBBLE KE, JARVIS G, BOCK M AND WELCH DBM. 2014. Maternal caloric restriction partially rescues the deleterious effects of advanced maternal age on offspring. Aging Cell 13: 623-630.

HAGIWARA A AND HINO A. 1989. Effect of incubation and preservation on resting egg hatching and mixis in the derived clones of the rotifer Brachionus plicatilis. Hydrobiologia 186/187: 415-421.

HAGIWARA A AND HINO A. 1990. Feeding history and hatching of resting eggs in the marine rotifer Brachionus plicatilis. Nippon Suisan Gakkaishi 56: 1965-1971.

HOTOS GN. 2002. Selectivity of the rotifer Brachionus plicatilis fed mixtures of algal species with various cell volumes and cell densities. Aquacult Res 33: 949-957.

HOTOS GN. 2003. Growth, filtration and ingestion rate of the rotifer Brachionus plicatilis fed with large (Asteromonas gracilis) and small (Chlorella sp.) celled algal species. Aquacult Res 34: 793-802.

JOHNSTON RK AND SNELL TW. 2016. Moderately lower temperatures greatly extend the lifespan of Brachionus manjavacas (Rotifera): Thermodynamics or gene regulation? Exp Gerontol 78: 12-22.

JOSÉ DE PAGGI SB AND DEVERCELLI M. 2011. Land use and basin characteristics determine the composition and abundance of the microzooplankton. Water Air Soil Poll 218: 93-108.

JOSÉ DE PAGGI S AND PAGGI JC. 1998. Zooplancton de ambientes acuáticos con diferentes estados tróficos y salinidad. Neotrópica 44: 95-106.

KIM HJ AND HAGIWARA A. 2011. Effect of female aging on the morphology and hatchability of resting eggs in the rotifer Brachionus plicatilis Müller. Hydrobiologia 662: 107-111.

LOWE CD, KEMP SJ, BATES AD AND MONTAGNES DJS. 2005. Evidence that the rotifer Brachionus plicatilis is not an osmoconformer. Mar Biol 146: 923-929.

LUBZENS E, GIBSON O, ZMORA O AND SUKENIK A. 1995. Potential advantages of frozen algae (Nannochloropsis sp.) for rotifer (Brachionus plicatilis) culture. Aquaculture 133: 295-309.

LUBZENS E, MINKOFF G AND MAROM S. 1985. Salinity dependence of sexual and asexual reproduction in the rotifer Brachionus plicatilis. Mar Biol 85: 123-126.

LUBZENS E, TANDLER A AND MINKOFF G. 1989. Rotifers as food in aquaculture. Hydrobiologia 186: $387-$ 400.

LUBZENS E, ZMORA O AND BARR Y. 2001. Biotechnology and aquaculture of rotifers. Hydrobiologia 446/447: $337-$ 353.
MALEKZADEH VIAYEH R, MOHAMMADI H AND SHAFIEI AB. 2010. Population growth of six Iranian Brachionus rotifer strains in response to salinity and food type. Internat. Rev Hydrobiol 95: 461-470.

MCCAULEY E. 1984. The estimation of the abundance and biomass of zooplankton in samples. In: Downing $\mathrm{J}$ and Rigle RF (Eds), A manual on methods for the assessment of secondary productivity in fresh waters, Boston: Blackwell Scientific Publications, p. 228-265.

MILLS S ET AL. 2016. Fifteen species in one deciphering the Brachionus plicatilis species complex (Rotifera, Monogononta) through DNA taxonomy. Hydrobiologia 796: 39-58.

MIRACLE MR AND SERRA M. 1989. Salinity and temperature influence in rotifer life history characteristics. Hydrobiologia 52: 81-102.

MONTERO-PAU J, RAMOS-RODRÍGUEZ E, SERRA M AND GÓMEZ A. 2011. Long-Term Coexistence of Rotifer Cryptic Species. PLoS ONE 6: e21530.

MONTGOMERY DC. 2013. Design and analysis of experiments, $8^{\text {th }}$ ed., New York: J Wiley \& Sons, Inc., 757 p.

PASCUAL E AND YÚFERA M. 1983. Crecimiento en cultivo de una cepa de Brachionus plicatilis O. F. Müller en función de la temperatura y la salinidad. Investigaciones Pesqueras 47: 151-159.

SARMA SSS, NANDINI S, MORALES-VENTURA J, DELGADO-MARTÍNEZ I AND GONZÁLEZVALVERDE L. 2006. Effects of $\mathrm{NaCl}$ salinity on the population dynamics of freshwater zooplankton (rotifers and cladocerans). Aquatic Ecol 40: 349-360.

SERRA M, GÓMEZ A AND CARMONA MJ. 1998. Ecological genetics of Brachionus sympatric sibling species. Hydrobiologia 387/388: 373-384.

STELZER CP AND SNELL TW. 2003. Induction of sexual reproduction in Brachionus plicatilis (Monogononta, Rotifera) by a density-dependent chemical cue. Limnol Oceanogr 48: 939-943.

SUATONI E, VICARIO S, RICE S, SNELL T AND CACCONE A. 2006. An analysis of species boundaries and biogeographic patternsin a cryptic species complex: The rotifer-Brachionus plicatilis. Mol Phylogenet Evol 41: 86-98.

SUCHAR VA AND CHIGBU P. 2006. The effects of algae species and densities on the population growth of the marine rotifer, Colurella dicentra. J Exp Mar Biol Ecol 337: 96-102.

VALLEJO IA, NEWMARK F AND CRIALES MM. 1993. Efecto de la salinidad sobre el crecimiento poblacional y el rendimiento del rotífero Brachionus plicatilis (cepa Ciénaga Grande de Santa Marta). An Inst Invest Mar Punta Betín 22: 112-121. 
VIGNATTI A, CABRERA G AND ECHANIZ S. 2012. Changes in the zooplankton and limnological variables of a temporary hypomesosaline wetland of the central region of Argentina during the drying. PanamJAS 7: 93-106.

WALCZYŃSKA A, FRANCH-GRAS L AND SERRA M. 2017. Empirical evidence for fast temperature-dependent body size evolution in rotifers. Hydrobiologia 796: 191200.

WALCZYŃSKA A AND SERRA M. 2014. Inter-and intraspecific relationships between performance and temperature in a cryptic species complex of the rotifer Brachionus plicatilis. Hydrobiologia 734: 17-26.

YIN XW AND ZHAO W. 2008. Studies on life history characteristics of Brachionus plicatilis OF Müller (Rotifera) in relation to temperature, salinity and food algae. Aquatic Ecol 42: 165-176.

YÚFERA M. 2007. Swimming behaviour of Brachionus plicatilis in relation to food concentration and feeding rates. Hydrobiologia 593: 13-18. 